\title{
Congenital Talipes Equinovarus (CTEV)
}

\author{
Richardo J. Laloan, ${ }^{1}$ Andriessanto C. Lengkong ${ }^{2}$
}

${ }^{1}$ Program Pendidikan Profesi Dokter Fakultas Kedokteran Universitas Sam Ratulangi Manado

${ }^{2}$ Divisi Ortopaedi dan Traumatologi Bagian Ilmu Bedah Fakultas Kedokteran Universitas Sam Ratulangi Manado

Email: richardojordan10@gmail.com

\begin{abstract}
Congenital talipes equinovarus (CTEV) is a type of foot deformities characterized with hindfoot varus, adducted metatarsus, wide arched of the foot (cavus), and equinus. Its incidence is $1.2 \%$ per 1000 births annually. Around $80 \%$ of cases occur as idiopathic type and the remaining $20 \%$ is associated with other anomaly conditions. Genetic component is considered to play a role in the occurrence of CTEV. However, up to this day, there is no exact underlying etiology that defines the exact pathogenesis of CTEV. The evolving etiology nowadays is still multifactorial. Management of CTEV varies from non-surgical treatment to surgical treatment. A number of scoring and grading using qualitative and quantitative measurement are being used nowadays to assess the severity of CTEV because this deformity needs long-term follow-up due to its tendency to relapse.
\end{abstract}

Keywords: congenital talipes equinovarus, clubfoot

\begin{abstract}
Abstrak: Congenital talipes equinovarus (CTEV), dikenal juga dengan true clubfoot, merupakan deformitas pada kaki yang ditandai oleh adanya bentuk varus kaki belakang, adduksi metatarsus, dan adanya bentuk lengkungan kaki yang lebar (cavus) serta equinus. CTEV merupakan salah satu dari deformitas kaki pada saat lahir dengan insidensi $1,2 \%$ per 1000 kelahiran hidup per tahunnya. Pada 80\% kasus terjadi secara idiopatik dan 20\% dikaitkan dengan kondisi-kondisi lain. Komponen genetik diduga berperan pada CTEV, namun, sampai saat ini, belum ada etiologi pasti yang menjelaskan patogenesis CTEV. Etiologi yang berkembang sampai saat ini bersifat multifaktorial. Tatalaksana pasien CTEV bervariasi mulai dari non-operatif maupun operatif. Sejumlah pengukuran kualitatif maupun kuantitatif telah dikembangkan untuk menilai keparahan CTEV berhubung kondisi deformitas ini membutuhkan follow-up jangka panjang karena mempunyai kecenderungan untuk relaps.
\end{abstract}

Kata kunci: congenital talipes equinovarus, clubfoot

\section{Pendahuluan}

Talipes equinovarus (clubfoot) berasal dari kata Latin yaitu talus berarti pergelangan kaki (ankle), pes berarti kaki, equinus berarti fleksi plantaris (horse-like), dan varus berarti terbalik dan adduksi. Literatur medis untuk talipes equinovarus diperkenalkan pertama kali oleh Hippocrates pada 400 SM, yang menyadari bahwa clubfoot dapat terjadi kongenital dan bermanifestasi defek yang terisolasi saat lahir tanpa adanya malformasi pada organ lain (80\% kasus) sehingga mencetuskan konsep istilah congenital talipes equino-varus (CTEV) idiopatik. ${ }^{1}$

Congenital talipes equinovasrus (CTEV) umumnya berupa idiopatik namun dapat dihubungkan dengan kondisi lain pada sekitar $20 \%$ kasus. Kondisi-kondisi yang paling sering dihubungkan dengan CTEV ialah spina bifida (4,4\% pada anak dengan CTEV), palsi serebral (1,9\%), dan artrogriposis $(0,9 \%)$. Berdasarkan jenis kelamin CTEV lebih sering dialami oleh laki-laki dibandingkan perempuan dan pada $50 \%$ 
kejadian merupakan kasus yang terjadi bilateral. $^{2}$

Insidensi CTEV ialah $1,2 \%$ per 1000 kelahiran hidup per tahunnya. Terdapat keterlibatan genetik pada penderita CTEV, yaitu jika salah satu orang tua memiliki CTEV maka risiko untuk memiliki keturunan yang memiliki CTEV ialah 3-4\%, dan jika kedua orang tua memiliki CTEV maka risiko pada keturunan selanjutnya meningkat sebesar $30 \%$. Jika satu anak memiliki CTEV, maka risiko terjadinya CTEV pada keturunan selanjutnya meningkat sampai 20 kali. $^{2,3}$

Tatalaksana pasien CTEV bervariasi mulai dari non-operatif maupun operatif, yang meliputi manipulasi ringan dan strapping, koreksi serial menggunakan casting, manipulasi dengan alat-alat mekanik sampai koreksi secara operatif. Dewasa ini umumnya bedah ortopedi sepakat bahwa terapi inisial untuk CTEV harus dimulai dengan metode non-operatif sejak hari pertama kehidupan agar deformitas dapat dengan mudah dikoreksi re-alignment, mendapatkan hasil fungsional yang baik, dan mencegah terjadinya relaps. ${ }^{4}$

Mengingat bahwa defek ini memiliki keterlibatan genetik dan memerlukan penanganan sedini mungkin maka penulis tertarik untuk menelusuri lebih lanjut baik dari aspek pencegahan yang dapat dikaitkan pada marriage counseling, maupun persiapan orang tua sejak masa prenatal, penanganan dini, dan rekonstruksi operatif lanjut agar dapat menjamin quality of life (QoL) yang layak.

\section{Etiologi}

Terdapat beberapa faktor yang telah disepakati sebagai penyebab terjadinya CTEV, yaitu faktor mekanik intrauterin, defek neuromuskular, defek plasma primer, perkembangan fetus yang terhambat, dan pola pewarisan poligenik. Berdasarkan teori Hippocrates, CTEV disebabkan oleh adanya kompresi dalam uterus (faktor mekanik) sehingga posisi kaki menjadi equinovarus. Parker dan Browne menjelaskan bahwa adanya kondisi lain dalam uterus seperti oligohidramnion dapat menyebabkan keter- batasan pergerakan fetus. Beberapa penelitian menyatakan bahwa CTEV merupakan hasil defek neuromuskular, namun penelitian lain menunjukkan tidak adanya gambaran abnormalitas pada penemuan histologik neuromuskular. Irani dan Sherman melakukan diseksi 11 kaki pasien equinovarus dan 14 kaki normal dan menyatakan tidak terdapat abnormalitas primer pada saraf, pembuluh darah, tendon, dan tempat insersi otot-otot namun secara konstan abnormalitas ditemukan pada bagian anterior talus. Talus yang undersized dan bagian anteriornya berotasi ke arah medial. Penelitian tersebut menyimpulkan bahwa deformitas mungkin berasal dari defek germ plasma primer. ${ }^{5}$

Terdapat dua dasar pengaruh perkembangan fetus yaitu lingkungan intrauterin dan pengatuh lingkungan. Pada tahun 1863, Heuter dan Von Volkman mengusulkan teori bahwa kehidupan embrionik awal yang terhambat ialah penyebab abnormalitas perkembangan fetus dan menyebabkan CTEV. Pengaruh lingkungan dalam hal ini pengaruh buruk akibat agen-agen teratogenik pada lingkungan fetus dan selama perkembangan fetus telah dijelaskan memiliki efek yang buruk seperti rubela dan thalidomide. Banyak peneliti percaya bahwa CTEV dan keterhambatan perkembangan terjadi akibat berbagai faktor-faktor lingkungan. Honein et al melaporkan bahwa paparan rokok berhubungan dengan faktor kausa penyebab CTEV terlebih khusus pada periode antenatal. Pada pola pewarisan poligenik, CTEV cenderung bersifat familial. Penelitian oleh Davis mendukung teori poligenik ini dan menunjukkan adanya pola pewarisan dari satu keturunan ke keturunan selanjutnya. Sekitar 2,9\% saudara kandung per 1-2 juta penduduk memiliki deformitas yang sama, dan memiliki risiko 25 kali untuk dialami oleh saudara kandung selanjutnya juga. ${ }^{5}$

\section{Embriologi}

Inisiasi limb bud embrio dimulai dengan terjadinya ekspresi gen homeobox (Hox) pada sel-sel mesoderm paraksial primitif yang dikontrol dari sinyaling faktor 
pertumbuhan fibroblas (fibroblast growth factor/FGF). Adanya ekspresi T-box transcription factor (Tbx4) nantinya akan menentukan pembentukan ekstremitas bagian bawah dari lateral plate mesoderm yaitu jaringan-jaringan ikat ekstremitas, seperti kartilago, tulang, tendon, dan otototot jaringan ikat. Ekspresi Tbx4 dalam membentuk area kaki diatur oleh homeodomain containing transcription factor Pitxl yang bekerja bersama dengan faktor transkrpsi Pitx2. Pitx1 diekspresikan pada lateral plate mesoderm di regio posterior tubuh dan merupakan penentu utama identitas kaki belakang ( hindlimb). ${ }^{6}$

Ekspresi limb-homeodomain containning transcription factor, Islet1, pada region yang sama di lateral plate mesoderm juga memiliki peranan penting untuk Tbx4 melakukan ekspresi dan formasi hindlimb bud. Gen-gen tersebut secara khusus diekspresikan untuk membentuk kaki. Bila terdapat defek genetik pada komponen apapun dalam gen-gen serta jalurnya maka akan menghasilkan defek pada ekstremitas. ${ }^{6}$

\section{Patogenesis}

Patogenesis CTEV meliputi faktor genetik, gen homebox (HOX), jalur PITX1TBX4, jalur gen caspases, jalur gen kolagen, gen GL13, dan gen T-box. Faktor genetik memiliki peranan penting pada perkembangan CTEV namun belum memiliki identifikasi pasti mengenai kandidat gen mayor yang berperan. Banyak penelitian menunjukkan terdapatnya bukti riwayat dalam keluarga pada 24-50\% kasus CTEV. Terdapat juga pelaporan kasus unik CTEV bilateral pada bayi triplets preterm, yang memberikan dukungan lebih lanjut akan etiologi dan patogenesis dasar genetik. ${ }^{7}$

Gen homeobox mewakili patogenesis melalui faktor transkripsi yang berperan utama pada proses morfogenesis perkembangan fetus embrionik. Secara khusus, gen ini berfungsi untuk menentukan genesis yang benar untuk berkembang menjadi tulang dan ekstremitas. Hal ini mendasari para peneliti yang mengusulkan gen ini sebagai kandidat patogenesis CTEV idiopatik. Penelitian skala besar yang dilakukan pada tahun 2016 menunjukkan bahwa CTEV berhubungan dengan alterasi pada domain regulator gen, yaitu HoxA dan HoxD. Berdasarkan data tersebut dapat diasumsikan bahwa gangguan pada klaster gen tersebut mungkin merupakan etiologi dan patogenesis CTEV. ${ }^{7}$

Protein TBX4 merupakan penentu faktor transkripsi yang diekspresikan pada hind-limb; oleh karena itu diduga protein ini memiliki hubungan dengan patogensis CTEV. Adanya mikrodelesi dan mikroduplikasi protein TBX4 banyak ditemukan pada pasien familial isolated clubfoot. Selanjutnya didapatkan bahwa gen PITX1, yaitu penentu faktor transkripsi lainnya, ternyata memiliki jalur yang sama dengan protein TBX4. Oleh karena jalur PITX1TBX4 secara langsung berpengaruh pada perkembangan awal ekstremitas, maka hal ini dihubungkan dengan CTEV. Beberapa penelitian melaporkan bahwa mutasi pada gen-gen yang mengkode faktor transkripsi PITX1 dan TBX4 menyebabkan anomali muskulatur ekstremitas bawah dan berhubungan dengan kejadian CTEV. Penelitian tahun 2017 melaporkan bahwa jalur PITX1TBX4 dapat dihubungkan dengan alterasi HOXC pada talus vertikal. Pada penelitian tersebut diidentifikasi adanya delesi gen HOXC13 yang ditemukan pada 3 generasi keluarga dengan CTEV. Mutasi jalur PITX1-TBX4-HOXC masih sangat jarang pada pasien CTEV; oleh karena itu mekanisme genetik lain perlu untuk diteliti. ${ }^{7}$

Cysteine-dependent aspartate-directed proteases (caspases) merupakan bagian dari sistein protease yang memainkan peranan esensial dalam proses apoptosis, nekrosis, dan proses inflamasi. Gen ini mulai diteliti sejak diketahui bahwa aktivitas caspases ternyata berhubungan dengan perkembangan ektremitas dan merupakan gen pertama diteliti yang memiliki hubungan dengan CTEV. Gen CASP10 ialah jenis lain dari gen caspases yang ditemukan berhubungan dengan CTEV.

Gen kolagen juga sering dihubungkan dengan CTEV. Fokus utama pada penelitian genetik telah mendapatkan bahwa terdapat hubungan dengan COL9A1 dan 
COL1A1. COL9A1 mengkode satu dari tiga rantai kolagen tipe IX, yaitu komponen kartilago hialin, sedangkan COL1A1 mengkode rantai pro-alfa 1 kolagen tipe 1 , yaitu sebuah komponen yang terdapat di hampir semua jaringan ikat yang banyak pada tulang dan tendon. Pada tahun 2008, telah dilaporkan bahwa terdapat ekspresi yang tinggi COL1A1 pada pasien dengan CTEV dibandingkan dengan pasien normal. Penelitian Wang et al melaporkan mengenai gen yang mengatur ekspresi COL91A1 (SOX9), yaitu varian dari COL1A1, dan ternyata ditemukan tidak ada mutase gen namun terdapat ekspresi gen SOX9 yang tinggi pada sel-sel otot pasien CTEV. ${ }^{7}$

Gen GLI3 ialah gen yang mengkode protein zinc tipe $\mathrm{C} 2 \mathrm{H} 2$. Suatu penelitian pada tahun 2005 menunjukkan adanya mutase gen yang berhubungan dengan kejadian CTEV. Pada tahun 2009, penelitian lain melaporkan adanya interaksi langsung antara rendahnya ekspresi gen HoxD13 dapat menyebabkan peningkatan kadar gen GLI3 selama pembentukan ekstremitas yang dipikirkan merupakan kunci penyebab pada patogenesis CTEV. ${ }^{7}$

Mutasi gen T-box terutama TBX3 dan TBX4, bekerja menekan faktor transkripsi yang berperan penting selama embriogenesis dan morfogenesis. Seperti halnya dengan gen yang telah disebutkan, gen ini juga termasuk kandidat kemungkinan menyebabkan CTEV. Gen-gen tersebut ditemukan memiliki ketidakseimbangan transmisi pada pasien CTEV. ${ }^{7}$

\section{Diagnosis}

Diagnosis CTEV ditegakkan berdasarkan anamnesis, pemeriksaan fisik, dan pemeriksaan penunjang (ultrasonografi, Xray, dan MRI). Pada anamnesis, perlu diketahui riwayat perinatal dan riwayat dalam keluarga. Riwayat mengenai malpresentasi intrauterin berkaitan dengan adanya faktor mekanik yang memengaruhi mobilitas fetus seperti presentasi sungsang, oligohidramnion selama kehamilan dapat dihubungkan dengan artrogriposis, malformasi uterin atau fibroid uterus, serta gestasi multipel. ${ }^{8,9}$ Diagnosis CTEV pada masa prenatal bisa terlihat pada sekitar usia kehamilan 20 minggu dan bila ditemukan adanya anomali saat pemeriksaan maka dibutuhkan konseling dan diskusi informasi dokter-pasien berhubungan dengan tatalaksana dan hasil tatalaksana nanti. Hal ini dapat mempersiapkan orang tua pasien secara emosional maupun praktikal nantinya. ${ }^{9}$

Diagnosis awal CTEV pada bayi baru lahir ditegakkan berdasarkan gambaran klinis. Pada pemeriksaan fisik ditemukan kaki belakang membentuk equinovarus dengan adanya adduksi kaki depan dan adanya cavus. Perlu diperhatikan bila adanya lipatan yang dalam pada bagian posterior dan bagian medial karena berhubungan dengan tingkat keparahan deformitas (Gambar 1). Bisa terdapat adanya atrofi betis (calf) pada bagian ipsilateral, bersamaan dengan pemendekan tendon Achilles dan rotasi internal pada tibia. Hal ini mungkin tidak dapat terlihat saat lahir namun akan lebih nampak seiring bertumbuhnya pasien. ${ }^{9}$

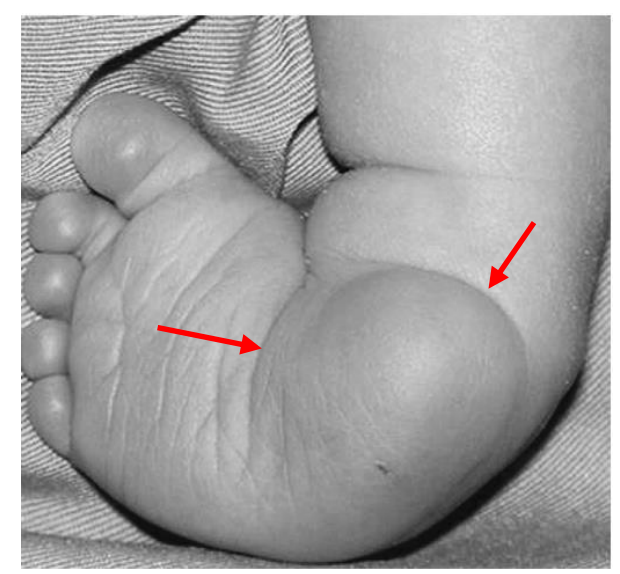

Gambar 1. Lipatan medial dan posterior. Sumber: Foster A, Davis N, $2010^{9}$

Pemeriksaan harus meliputi pemeriksaan spinal dan pemeriksaan neurologik lengkap. Sendi-sendi lain juga harus diperiksa berkenaan dengan apakah terdapat kekakuan dan deformitas, termasuk sendi panggul yang harus diperiksa dengan ultrasound untuk mendeteksi displasia khususnya pada postural clubfoot sebagai bagian dari moulded baby syndrome. ${ }^{9}$

Pemeriksaan penunjang yang dapat dilakukan ialah ultrasonografi, X-ray, dan 
magnetic resonance imaging (MRI). Diagnosis menggunakan ultrasound selama masa prenatal dapat memperlihatkan serta mengonfirmasi permukaan plantar pedis, tibia, dan fibula pada satu sisi. Namun, penemuan pada ultrasound tidak berkorelasi dengan derajat keparahan CTEV dan tidak dapat digunakan sebagai patokan terapi, berhubung tidak adanya pilihan tatalaksana pada masa prenatal yang tersedia. ${ }^{9,10}$ Jika CTEV tidak teridentifikasi saat prenatal maka pilihan dan waktu melahirkan tidak akan berubah. Hal ini juga serupa bila didapatkan penemuan yang lebih kompleks, misalnya CTEV disertai adanya clenched hands yang dihubungkan dengan amioplasia, maka kemungkinan besar indikasi untuk melahirkan secara sesar. Riwayat CTEV yang terisolasi atau CTEV bilateral pada orang tua atau dalam keluarga dapat dijadikan patokan dalam kasus CTEV idiopatik. Penggunaan radiografi memiliki keterbatasan karena hanya kecil kemungkinan terdeteksinya osifikasi tulang kaki pada masa bayi baru lahir yang menyulitkan interpretasi. Pencitraan radiografi yang dilakukan secara tersimulasi pada daerah weight-bearing antero-posterior dan lateral dorsofleksi maksimum (Turco's view) dapat bermanfaat dalam menentukan waktu dilakukan operasi pada anak. ${ }^{10}$

Pemeriksaan MRI dapat bermanfaat dalam memperlihatkan kelainan talipes equinovarus pada fetus, terlebih khusus bila dicurigai memiliki kelainan kompleks. Dengan MRI dapat dideteksi anomali tambahan, seperti pada sistem neurologik, namun MRI dianggap tidak membantu dalam kasus CTEV yang terisolasi. ${ }^{10}$

\section{Klasifikasi}

Secara global, sistem klasifikasi yang paling sering digunakan pada CTEV ialah klasifikasi Dimeglio dan klasifikasi Pirani. Sistem klasifikasi Dimeglio menjelaskan berdasarkan koreksi yang diperoleh setelah dilakukan kekuatan reduksi ringan pada kaki yang mengalami deformitas. Pada sistem klasifikasi ini terdapat 4 parameter yang dinilai yaitu: 1) deviasi equinus pada sisi sagital; 2) deviasi varus pada sisi frontal; 3) derotasi pada sekitar talus ke calcaneoforefoot block; dan 4) adduksi kaki depan pada sisi horizontal. Nilai maksimal yang diperoleh berjumlah 16 untuk kaki yang paling kaku. Terdapat tambahan 4 poin untuk penilaian bila terdapat 4 tanda kegawatan: lipatan plantar, lipatan medial, retraksi cavus, dan fibrosis otot (Tabel 1 dan 2). ${ }^{11}$

Sistem klasifikasi Pirani mengevaluasi 6 tanda klinis kontraktur yang merupakan karakteristik klinis pada CTEV (Tabel 3). Setiap tanda pada sisi yang mengalami deformitas dibandingkan dengan bagian normal yaitu sisi sebelahnya. Hal ini dilakukan pada deformitas yang terbatas pada satu sisi saja. ${ }^{11}$

Tabel 1. Poin-poin pada klasifikasi CTEV Dimeglio dan elemen-elemen kegawatan ${ }^{11}$

\begin{tabular}{lc}
\hline \multicolumn{1}{c}{ Variabel } & Nilai \\
\hline Reduksibilitas & \\
$45^{\circ}-90^{\circ}$ & 4 \\
$20^{\circ}-45^{\circ}$ & 3 \\
$0^{\circ}-20^{\circ}$ & 2 \\
$-20^{\circ}-0^{\circ}$ & 1 \\
$>-20^{\circ}$ & 0 \\
Elemen-elemen kegawatan & \\
Lipatan posterior & 1 \\
Lipatan medial & 1 \\
Cavus & 1 \\
Fibrosis otot-otot & 1 \\
Skor total & $0-20$ \\
\hline
\end{tabular}

\section{Penatalaksanaan}

Metode Ponseti merupakan pilihan yang digunakan untuk bayi dengan CTEV pada banyak senter di seluruh dunia karena metode ini merupakan terapi non invasif. CTEV yang diterapi dengan metode Ponseti memiliki keluaran mobilitas dan fungsional yang baik. Metode terapi ini diutamakan pada bayi sampai usia $<2$ tahun agar supaya mencegah kelemahan jaringan ikat dan potensi dalam remodeling tulang diharapkan bisa maksimal. ${ }^{12}$

Pada anak berusia $>2$ tahun koreksi masih dapat dicapai dengan modifikasi minor menggunakan teknik terapi ini. Walaupun koreksi komplit tidak tercapai namun setidaknya dapat membantu dalam mengurangi luas area operasi kelak dan me- 
Tabel 2. Derajat klasifikasi CTEV Dimeglio ${ }^{11}$

\begin{tabular}{cccc}
\hline Derajat & Tipe & Skor & Reduksibilitas \\
\hline I & Ringan & $<5$ & $>90^{\circ}$, lunak-lunak, tereduksi \\
II & Sedang & $5-10$ & $>50^{\circ}$, lunak-keras, tereduksi, sebagian kaku \\
III & Berat & $10-15$ & $<50^{\circ}$, keras-lunak, keras, sebagian tereduksi \\
IV & Sangat berat & $15-20$ & $<10^{\circ}$, keras-keras, kaku \\
\hline
\end{tabular}

Tabel 3. Klasifikasi CTEV Pirani ${ }^{11}$

\begin{tabular}{lc}
\hline \multicolumn{1}{c}{ Variabel } & Skor \\
\hline Skor kontraktur kaki belakang & $0-3$ \\
Lipatan posterior (dorsal) & $0,0,5,1$ \\
Kekosongan tumit & $0,0,5,1$ \\
Derajat dorsofleksi & $0,0,5,1$ \\
Skor kontraktur kaki bagian tengah & $0-3$ \\
Kelengkungan batas lateral & $0,0,5,1$ \\
Lipatan medial & $0,0,5,1$ \\
Tereksposnya kepala lateral talus & $0,0,5,1$ \\
Skor total & $0-6$ \\
\hline
\end{tabular}

nurunkan komplikasi infeksi atau luka sesudah operasi. Sampai saat ini tidak diketahui batasan usia maksimal untuk melakukan terapi ini. ${ }^{12}$

Keparahan deformitas dievaluasi menggunakan klasifikasi Dimeglio pada presentasi klinis awal. Sebelumnya diperlukan foto radiologik posisi anteroposterior (AP) kaki dalam posisi abduksi dan posisi lateral kaki dalam posisi dorsifleksi maksimal dan fleksi plantar. ${ }^{13}$ Terapi deformitas terdiri dari manipulasi ringan pada kaki dan serial casting dengan maksimal 10 kali menggunakan long-leg cast setiap minggunya.
Selama masa ini, akan didapatkan hasil jelas jika tatalaksana non-operatif akan berhasil atau tidak dan membutuhkan tatalaksana secara operatif. ${ }^{13,14}$

Setelah selesai serial cast, dibutuhkan follow-up dengan pemeriksaan radiologik kaki untuk melihat hasil koreksi. Jika koreksi telah dicapai, maka dilakukan pemasangan tipe ortosis abduksi Dennis-Brown (Gambar 2). Namun, jika pada follow-up belum terlihat perubahan bermakna, maka perlu dilakukan tenotomi tendon Achilles pada usia 6 sampai 12 bulan setelah lahir. ${ }^{13}$

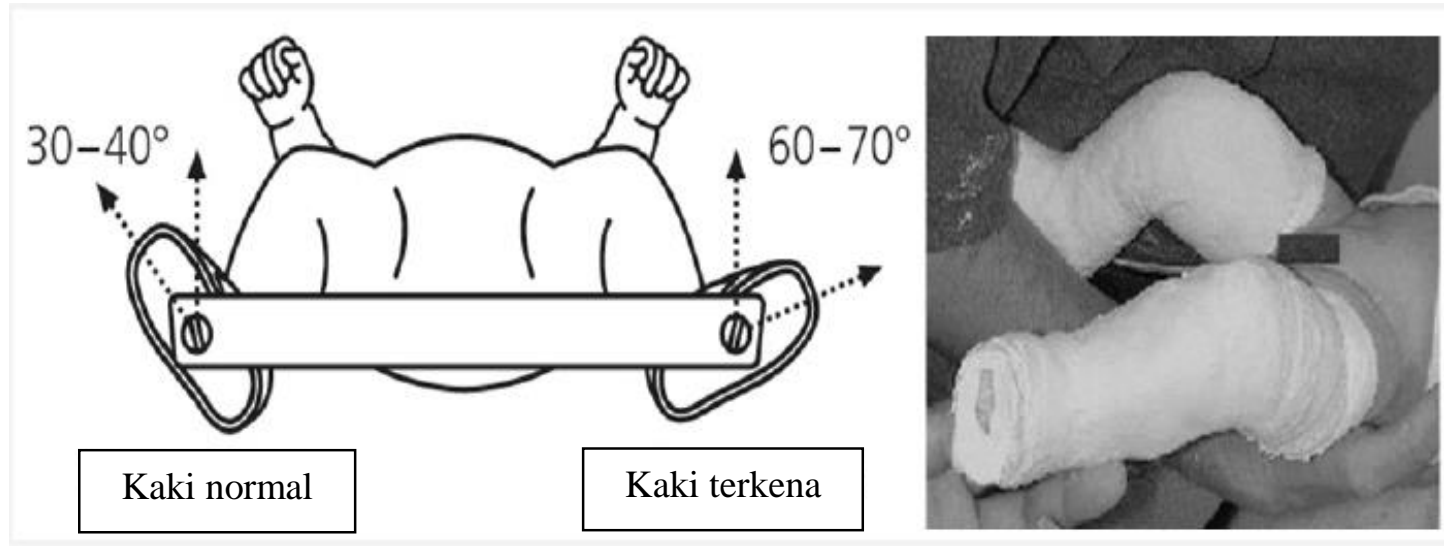

Gambar 2. Metode Ponseti dan Foot Abduction Brace (FAB) tipe Dennis-Brown. Sumber: Manisha R, Priyanka K, $2017^{5}$ 
Selain metode Ponseti, dapat juga dilakukan terapi fisik metode French yang terdiri atas manipulasi harian, stimulasi otototot kaki untuk mempertahankan kekuatan kaki saat manipulasi pasif, dan imobilisasi temporer kaki menggunakan strapping adesi elastik maupun non-elastik. Terapi biasanya dilakukan sekitar 2 bulan dan kemudian frekuensinya dikurangi secara perlahan dan bertahap. Perbaikan biasanya terjadi pada 3 bulan pertama, meskipun capaian menggunakan terapi ini lebih lama dari metode Ponseti. ${ }^{14}$ Metode French ini dilakukan oleh ahli terapis dan dimulai sejak jam-jam pertama setelah bayi lahir dengan melakukan koreksi secara perlahan dan bertahap dan dilakukan sesuai prinsip Scarpa: saat melakukan manipulasi, bayi harus dalam keadaan rileks. Pada saat bayi lahir, hanya $35 \%$ tulang kaki yang berosifikasi dan tulang masih seperti seperti kartilago yang fleksibel. ${ }^{15}$

Tatalaksana operatif yang sering digunakan dewasa ini ialah posteromedial release (PMR). Metode PMR merupakan tindakan operasi yang dilakukan pada kasuskasus CTEV yang tidak terkoreksi atau relaps saat pasien sudah bisa berjalan. ${ }^{13,16}$ Setelah koreksi operatif berhasil dicapai, dilanjutkan dengan pemasangan $3 \mathrm{~K}$-wires, dengan mentransfiksasi pertama sendi kalkaneokuboid, dilanjutkan dengan talonavikular kemudian pergelangan kaki. Kemudian dilakukan penjahitan tendon Achilles dan tendon tibial posterior. K-wires akan dilepas 4 minggu setelah operasi, dan kaki pasien kemudian akan diimobilisasi menggunakan cast selama 6 minggu setelah operasi pelepasan K-wires. Follow-up setelah operasi dilakukan dengan foto $\mathrm{X}$-ray kaki posisi AP dan lateral serta X-ray kaki lateral dalam posisi dorsifleksi maksimal dan fleksi plantar maksimal. ${ }^{13}$

Pasien diinstruksikan mengikuti followup antara 1-3 bulan interval dan latihan range-of-motion (ROM) selalu diedukasi kepada keluarga untuk meningkatkan fleksibilitas. Pada beberapa kasus, intoleransi menggunakan brace merupakan salah satu alasan utama terjadinya masalah kejadian ulang (re-occurrence), sehingga membutuh- kan pengulangan tatalaksana dari awal dengan serial casting dan manipulasi serta diperlukan untuk merencanakan prosedur operatif. Pada anak berusia di atas 3 tahun hanya dibutuhkan serial casting selama 6 minggu untuk memfasilitasi peregangan otot tanpa menggunakan brace abduksi kaki. Jika posisi yang diatur sesuai selama terapi, maka akan dilanjutkan dengan operasi transfer tendon anterior tibialis ke tulang kuneiform ketiga. ${ }^{5}$

Salah satu terapi tambahan masa postnatal dalam tatalaksana CTEV ialah dengan injeksi BOTOX (BTX). Onabotulinumtoxin A berasal dari derivat Clostridum botulinum tipe A atau botulinum toxin (BTX). Injeksi BTX dapat menginhibisi pelepasan asetilkolin ke celah neuromuskular sehingga secara parsial memberikan efek denervasi serat otot dan menyebabkan paralisis otot yang terlokalisasi. Indikasi pada kelompok pediatrik untuk injeksi BTX ini telah berkembang dan masuk dalam tatalaksana kelainan kondisi otot skeletal. ${ }^{17}$

Injeksi BTX untuk terapi CTEV diberikan satu atau kombinasi pada kelompok otot berikut: $m$. gastrocnemius, $m$. soleus, m. tibialis posterior, dan m. adductor halluces longus. Onabotulinumtoxin A diberikan dengan diencerkan pada larutan salin yaitu $100 \mathrm{U} / 1 \mathrm{~mL}$, sehingga menjadi larutan konsentrasi $10 \mathrm{U} / 0,1 \mathrm{~mL}$. Kuantitas untuk injeksi BTX ditentukan menurut berat badan pasien, dimana dosis $10 \mathrm{U} / \mathrm{kgBB}$ dengan dosis maksimal $300 \mathrm{U}$ untuk sekali injeksi. Pada pasien CTEV bilateral, maka dosis yang dihitung dibagi dua untuk dua ekstremitas. Efek samping yang pernah dilaporkan setelah penggunaan Onabotulinumtoxin A pada pasien CTEV ialah infeksi viral, infeksi telinga, kesadaran somnolen, gangguan gait, parestesia, ruam, mialgia, kelemahan otot, nyeri pada ekstremitas, inkontinensia urin, malaise, nyeri pada daerah injeksi, dan astenia. ${ }^{17}$

\section{Komplikasi}

Komplikasi yang dapat terjadi dibagi atas komplikasi non operatif dan operatif. Pada komplikasi non-operatif dapat ditemu- 
kan flat top talus, rocker bottom, dorsal bunion, distal tibiofibular bowing, fraktur, dan luka akibat tekanan. Flat top talus diduga terjadi secara iatrogenik, namun durasi dari manipulasi dan pemasangan casting lebih dari 3 bulan dapat juga menyebabkan kelainan ini. Perlu diketahui bahwa deformitas ini sebenarnya sudah terdapat sejak lahir. Flat top talus dapat disalah-diagnosis karena posisi x-ray lateral pasien CTEV sering memperlihatkan talus pada posisi proyeksi oblik, sehingga menunjukkan gambaran flat talar dome. ${ }^{18,19}$ Deformitas rocker bottom merupakan komplikasi tersering akibat tatalaksana non-operatif manipulasi pada CTEV dengan insidensi $3,2 \%$ di seluruh dunia. ${ }^{20}$ Prinsip penyebab rocker bottom ialah percobaan koreksi equinus pada hindfoot sebelum forefoot, sehingga varus hindfoot terbuka (koreksi varus). Kite telah mengindikasikan bahwa ketika hindfoot dan forefoot dibuka, maka equinus hampir selalu dapat dikoreksi. Umumnya terapi koreksi berulang dapat menyebabkan rocker-bottom foot. Setelah munculnya komplikasi ini, maka operasi posteriror release dibutuhkan dengan segera. ${ }^{18}$ Dorsal bunion ini ditandai oleh adanya peninggian pada metatarsal I dan muskulus fleksor halusis brevis yang berkontraksi pada tampakan pemeriksaan fisik. ${ }^{19}$ Pada distal tibiofibular bowing, posisi bowing selalu berada di bagian posterior dan/atau medial, sehingga menunjukkan derajat fibula akan tibia menjadi besar. Bowing yang terjadi biasanya ringan dan dapat didiagnosis hanya dengan x-ray. Penyebab terjadinya bowing disebabkan akibat dorsifleksi paksa dengan terkanan berlebihan. ${ }^{18}$ Beberapa fraktur yang dapat terjadi ialah: 1) Kompresi metafiseal, yang diduga disebabkan oleh kompresi anterior pada metafisis tibia dan fibula bagian distal ditambah dengan dorsifleksi paksa pada kaki; 2) Distal tibial metaphyseal spur, disebabkan karena adanya infark piring epifiseal. Lokasinya mengindikasikan akibat dorsifleksi paksa; 3) Fraktur torus pada metafisis distal tibia, yang terjadi di antara piring epifiseal dengan penyebab diduga akibat dorsofleksi paksa; 4) Faktur fibula distal, yang disebabkan karena adanya eversi paksa atau dorsifleksi paksa. Luka akibat tekanan kadang-kadang muncul akibat tekanan yang diberikan pada bagian superfisial. $^{18}$

Komplikasi operatif dapat berupa overcorrection, nonunion of triple arthrodeses, slough atau jaringan nekrotik, dan infeksi luka. Pasien dengan overcorrected biasanya datang beberapa tahun setelah operasi. Gejala onset akut yang muncul ialah simtomatik dan biasanya berhubungan dengan trauma minor sehingga pasien dapat mengeluhkan sprain. Sampai usia dewasa muda, gejala yang muncul ialah kekakuan yang sering terjadi sekitar deformitas sehingga membatasi aktivitas. Hal ini menyebabkan ketidaknyamanan dan kesulitan pasien dalam memakai sepatu. ${ }^{19}$ Nonunion of triple arthrodesis merupakan kasus non-union tulang pada pasca operasi yang dapat dihindari dengan teknik operasi yang baik. Slough atau jaringan nekrotik pada bagian anterior sendi pergelangan kaki yang terjadi akibat kesalahan dalam pengaplikasian plaster setelah operasi, dimana plester menumpuk pada bagian anterior pergelangan kaki dan akan terjadi penekanan pada daerah tersebut. Infeksi luka jarang terjadi, hanya sebesar $<1 \%$ setelah operasi. $^{18}$

Pasca operasi dapat terjadi rekurensi dan masalah perkembangan motorik kasar. Kaki memiliki struktur anatomi dan biomekanik yang kuat dan terdiri atas tulang dan terhubung dengan struktur jaringan lunak. Bila dilakukan kesalahan dalam proses terapi koreksi, maka kemungkinan besar akan terjadi rekurensi deformitas kelak. Rekurensi deformitas ditandai dengan metatarsus adduktus, abduksi kaki, kehilangan kemampuan dorsifleksi dan supinasi dinamis yang nampak pada gait analysis ketika pasien mulai berjalan. Mengenai masalah perkembangan motorik kasar, seiring bertambahnya usia pasien, analisis gait menunjukkan bahwa bahkan setelah terapi deformitas CTEV dan pasien sudah berada pada keadaan plantigrade foot yang secara fungsional bisa sempurna dalam berjalan seperti kaki normal, namun saja tetap masih 
didapatkan berbeda bila dibandingkan dengan kaki normal seusianya. ${ }^{21}$

\section{Diagnosis Banding}

Sebagai diagnosis banding dari CTEV ialah congenital vertical talus (CVT), postural clubfoot atau positional talipes, dan metatarsus adductus. Congenital vertical talus merupakan deformitas kekakuan kaki yang ditandai dengan adanya dislokasi sendi talonavikular dan posisi tulang navikular berada pada bagian dorsal. Sekitar 50\% kasus mempunyai hubungan dengan artrogriposis dan anomali kromosom seperti trisomi 18. Perbedaan dengan CTEV adalah CVT tidak akan terkoreksi maksimal hanya dengan imobilisasi menggunakan cast, namun lebih membutuhkan operasi rekonstruksi minor maupun mayor. ${ }^{22}$ Pada pemeriksaan fisik, pasien CVT dapat menunjukkan Persian slipper foot yang sering dikaitkan dengan Freeman-Sheldon syndrome. Pada palpasi, talus dapat teraba berada ke arah medial. Posisi forefoot terlihat abduksi dan dorsifleksi sedangkan posisi hindfoot terlihat equinovalgus. ${ }^{23}$

Postural clubfoot atau positional talipes merupakan keadaan normal pada bayi baru lahir yang dapat memengaruhi satu atau kedua kaki, serta merupakan bentuk kondisi yang ringan dari CTEV, dimana tidak ditemukan adanya kontraktur yang bermakna dan lipatan kulit yang dalam (deep skin creases). Pada postural clubfoot kaki terlihat membentuk posisi adduksi namun masih fleksibel, oleh karena itu dapat digerakkan perlahan ke posisi normal kaki. Kondisi ini disebabkan karena posisi bayi in utero. Tatalaksana lain dari postural clubfoot yaitu beragam mulai dari stretching, splinting dan casting yang normalnya kaki pasien dapat dengan mudah terkoreksi tanpa harus melalui operasi. Postural clubfoot biasanya membaik sendiri pada beberapa bulan pertama. $^{24,25}$

Metatarsus adductus (MA) yang dikenal juga sebagai metatarsus varus atau metatarsus adductovarus, merupakan deformitas bentuk melintang dimana metatarsal berdeviasi ke arah medial. Pada MA umum- nya tidak ditemukan adanya deformitas lain, namun sangat berkorelasi dengan hallux valgus (HV). Dengan adanya MA maka risiko berkembang kearah $\mathrm{HV}$ meningkat 34 kali lipat. ${ }^{26}$

\section{Prognosis}

Hasil penelitian menunjukkan bahwa semakin tinggi derajat rigiditas deformitas atau nilai Dimeglio 16-20, dapat menyebabkan peningkatan risiko rekurensi setelah proses terapi koreksi pertama, namun dengan terapi ulang menggunakan metode Ponseti pasien masih dapat berespon terhadap terapi. ${ }^{27}$

Kejadian CTEV bilateral meningkatkan prognosis buruk dibandingkan hanya unilateral. Pasien pada kategori Dimeglio yang berat berhubungan dengan kualitas kegagalan terapi; oleh karena itu kebutuhan terapi yang sedini mungkin sangat diperlukan karena berhubungan dengan angka keberhasilan yang tinggi. ${ }^{28}$

\section{Simpulan}

Congenital talipes equinovarus (CTEV) merupakan deformitas pada kaki bayi baru lahir, umumnya idiopatik namun dapat dihubungkan dengan kondisi-kondisi penyerta lainnya. Komponen genetik diduga berperan pada CTEV.

Diagnosis CTEV diusahakan sedini mungkin agar dapat segera direncanakan terapi yang sesuai. Diagnosis awal CTEV pada bayi baru lahir ditegakkan berdasarkan gambaran klinis. Sistem klasifikasi diagnosis yang paling sering secara global digunakan pada CTEV ialah klasifikasi Dimeglio dan klasifikasi Pirani. Namun, hubungan antara hasil klasifikasi klinis dengan prognosis tatalaksana masih belum jelas.

Tatalaksana pasien CTEV bervariasi mulai dari non-operatif maupun operatif. Meskipun koreksi pada CTEV idiopatik telah dilakukan, namun prediksi angka kasus relaps juga tinggi, sehingga membutuhkan terapi secepat mungkin setelah bayi lahir. Bila terjadi relaps, dengan terapi ulang menggunakan metode Ponseti pasien masih dapat menunjukkan respon terhadap terapi. 


\section{Konflik Kepentingan}

Penulis menyatakan tidak terdapat konflik kepentingan dalam studi ini.

\section{DAFTAR PUSTAKA}

1. Nordin S, Aidura M, Razak S, Faisham WI. Controversies in congenital clubfoot: Literature review. Malaysian Journal of Medical Science. 2002;9(1):34-40.

2. Bridgens J, Kiely N. Current management of clubfoot (congenital talipes equinovarus) clinical review. BMJ. 2010;340: 308-12. DOI: $10.1136 /$ bmj.c355

3. Zhang G, Zhang Y, Li M. A modified Ponseti method for the treatment of rigid idiopathic congenital clubfoot. J Foot Ankle Surg. 2019;58(6):1192-6. DOI: 10.1053/j.jfas.2019.04.003

4. Mohan S, Kumar S, Prashanth L, Krishnagopal R Management of idiopathic clubfoot by Ponseti's technique. IJOS. 2018;4(1): 92-7. DOI: https://doi.org/10.22271/ ortho.2018.v4.i1b.16

5. Manisha R, Priyanka K. Congenital clubfoot: a comprehensive review. Ortho \& Rheum Open Access. 2017;8(1):1-5, 555728. DOI: 10.19080/OROAJ.2017.08.555728

6. Basit S, Khoshhal KI. Genetics of clubfoot; recent progress and future perspectives. Eur J Med Genet. 2018;61(2):107-13. DOI:10.1016/j.ejmg.2017.09.006

7. Pavone V, Chisari E, Vescio A, Lucenti L, Sessa G, Testa G. The etiology of idiopathic congenital talipes equinovarus: a systematic review. J Orthop Surg Res. 2018;13(1):1-11. DOI:10. 1186/s13018-018-0913-z.

8. Amihood S, Idit M, Ehud B, Feldman BH, Chana V, Shay BS, et al. Prenatal clubfoot increases the risk for clinically significant chromosomal microarray results - analysis of 269 singleton pregnancies. Early Hum Dev. 2020;145: 105047. DOI:10.1016/j.earlhumdev.20 20.105047

9. Foster A, Davis N. congenital talipes equinovarus (clubfoot). Surgery (Oxford). 2007;25(4):171-5.

DOI:10.1016/j.mpsur.2007.04.001

10. Krakow D. Clubfoot (talipes equinovarus) and clenched hands. In: Copel JA, Feltovich H, Krakow D, Platt LD, D'Alton ME, Gratacos E, et al, editors. Obstetric Imaging: Fetal Diagnosis and Care. 2018; p. 305-8.e1. DOI:10.1016/b978-

\section{0-323-44548-1.00063-2}

11. Cosma D, Vasilescu DE. A Clinical evaluation of the pirani and dimeglio idiopathic clubfoot classifications. J Foot Ankle Surg.2015;54(4):5825. DOI:10.1053/j.j fas.2014.10.004

12. Banskota B, Banskota AK, Regmi R, Rajbhandary T, Shrestha OP, Spiegel DA. The Ponseti method in the treatment of children with idiopathic clubfoot presenting between five and ten years of age. Bone Joint J. 2013;95B(12):1721-5. DOI:10.1302/0301620x.95b12.32173

13. Machida J, Inaba Y, Nakamura N. Management of foot deformity in children. $\mathrm{J}$ Orthop Sci. 2017:22(2):175-83. DOI:10.1016/j.jos.2016.12.009

14. Richards BS, Faulks S, Rathjen KE, Karol LA, Johnston CE, Jones SA. A comparison of two nonoperative methods of idiopathic clubfoot correction: the Ponseti method and the French functional (physiotherapy) method. J Bone Joint Surg Am. 2008;90(11):2313-21. DOI: 10.2106/JBJS.G.01621

15. Dimeglio A, Canavese F. The French functional physical therapy method for the treatment of congenital clubfoot. J Pediatr Orthop B. 2012;21(1):28-39. DOI:10.1097/bpb.0b013e32834ee5f8

16. Zuber M, Jahan I, Kumar S. Management of congenital talipes equinovarus by Ponseti Method. J Evol Med Dent Sci. 2014;3(53):12344-57. DOI: 10.14260/ jemds/2014/3631

17. Chhina H, Howren A, Simmonds A, Alvarez CM. Onabotulinumtoxin $A \circledR$ injections: a safety review of children with clubfoot under 2 years of age at BC Children's Hospital. Eur J Paediatr Neuro. 2014; 18(2):171-5. DOI:10.1016/j.ejpn.2013.11.002

18. Weseley MS, Barenfeld PA, Barrett N. Complications of the treatment of clubfoot. Clin Orthop Relat Res. 1972;84: 93-6. DOI:10.1097/00003086197205000-00017

19. Burger D, Aiyer A, Myerson MS. Evaluation and surgical management of the overcorrected clubfoot deformity in the adult patient. Foot Ankle Clin. 2015; 20(4):587-99. DOI:10.1016/j.fcl.2015.07.006

20. Zhang W, Cai H. Management of rocker- 
bottom deformity during Ponseti treatment of congenital idiopathic clubfoot. Int J Clin Exp Med. 2019; 12(12):13805-11. DOI: 1940-5901/IJCEM0100125

21. Sayit E, Uruc V. The treatment of clubfoot with the Ponseti method: a systematic review. J Clin Anal Med. 2014;5(3): 400-4.

DOI: 10.4328/JCAM.2791

22. Aydın A, Atmaca H, Müezzinoğlu ÜS. Bilateral congenital vertical talus with severe lower extremity external rotational deformity. Foot. 2012;22(3): 252-4. DOI:10.1016/j.foot.2012.04.004

23. Mckie J, Radomisli T. Congenital vertical talus: a review. Clin Podiat Med Surg. 2010;27(1):145-

56. DOI:10.1016/j.cpm.2009.08.008

24. Chaweerat R, Kaewpornsawan K, Wongsiridej P, Payakkaraung S, Sinnoi S, Meesamanpong S. The effectiveness of parent manipulation on newborns with postural clubfoot: a randomized con- trolled trial. J Med Assoc Thai. 2014; 97(9):68-72.

25. The Royal Children's Hospital Melbourne. Positional Talipes. Orhtopaedic Fact Sheet 44. 2011. [cited 2020 Jun 30]. Available from: https://www.rch.org.au/ uploadedFiles/Main/Content/ortho/facts heets/POSITIONAL-TALIPES.pdf

26. Varacallo M, Aiyer A. Metatarsalgia in metatarsus adductus patients. Foot Ankle Clin.2019;24(4):657-67. DOI:10.1016/j.fcl.2019.08.002

27. Gunalan R, Mazelan A, Lee YPB, Saw A. Pattern of presentation and outcome of short-term treatment for idiopathic clubfoot/CTEV with Ponseti method. Malaysian Orthopaedic Journal. 2016; 10(3):21-5. DOI: http://dx.doi.org/ 10.5704/MOJ.1611.009

28. El Batti S, Solla F, Clément J-L, Rosello O, Oborocianu I, Chau E, et al. Initial treatment of congenital idiopathic clubfoot: prognostic factors. Orthop Traumatol Surg Res. 2016;102(8):10815. DOI:10.1016/j.otsr.2016.07.012 